\title{
PENGARUH PENAMBAHAN PROBIOTIK TERHADAP KUALITAS AIR BUANGAN BUDIDAYA UDANG MILIK PT. PULAU MAS KHATULISTIWA (STUDI KASUS: SUNGAI PINYUH, KABUPATEN MEMPAWAH)
}

\author{
Ria Risti Aatanti ${ }^{1}$ ) Dra Siti Khotimah, M.Si ${ }^{1}$ ) Isna Apriani, ST.M.Si ${ }^{2}$ ) \\ Program Studi Teknik Lingkungan Jurusan Teknik Sipil Fakultas Teknik Universitas \\ Tanjungpura Pontianak \\ Email: Riaristiastanti@yahoo.co.id
}

\begin{abstract}
ABSTRAK
Budidaya udang tambak merupakan komoditas yang sangat menjanjikan keuntungan, salah satu perusahaan tambak udang yang ada di Kalimantan Barat adalah tambak udang PT. Pulau Mas Khatulistiwa yang berada di Sungai Pinyuh. Pada proses budidaya udang tambak banyak menghasilkan bahan organik, tingginya bahan organik ini berasal dari sisa pakan (pellet) yang tidak habis, selain itu sisa metabolisme udang juga menghasilkan bahan organik. Oleh sebab itu untuk mengurangi bahan organik yang dihasilkan, PT Pulau Mas menambahkan probiotik (Bacillus sp.) ke dalam pakan udang. Penelitian ini bertujuan untuk mengetahui pengaruh penambahan probiotik terhadap kualitas air buangan budidaya udang tambak dan juga pertumbuhan udang secara fisik.

Tahapan penelitian ini yaitu pengumpulan data primer berupa pengambilan sampel air dan pengukuran berat udang. Pengambilan sampel kualitas air menggunakan metode grab sample pada dua kolam berbeda, yaitu kolam dengan penambahan probiotik dan kolam tanpa probiotik. Pengambilan sampel dilakukan dua kali yaitu pada saat udang berumur 2 bulan dan 3 bulan (panen). Adapun parameter yang diujikan yaitu BOD, COD, Amoniak, Nitrit dan $\mathrm{pH}$.

Berdasarkan hasil analisis diketahui bahwa penambahan probiotik pada pakan udang dapat mempenagruhi kualitas air buangan tambak udang, terlihat dari adanya penurunan konsentrasi yang lebih besar pada kolam dengan penambahan probiotik dibandingkan kolam tanpa probiotik. Kolam dengan probiotik dapat menurunkan BOD sebesar 92\%, COD 92\% dan Nitrit 75\%, sedangkan penurunan yang terjadi pada kolam tanpa probiotik untuk parameter BOD hanya sebesar $74 \%$, COD $69 \%$ dan Nitrit $88 \%$. Penambahan probiotik pada pakan udang dapat mempengaruhi pertumbuhan udang. Udang dengan penambahan probiotik memiliki pertumbuhan rata - rata sebesar 0,624 gram/hari, sedangkan udang tanpa penambahan probiotik pertumbuhan rata - ratanya hanya sebesar 0,41 gram/hari.
\end{abstract}

Kata-kata Kunci: Udang, Probiotik, Kualitas air

\section{ABSTRACT}

Shrimp culture ponds is a commodity that is very promising advantages, one of the existing shrimp farm in West Kalimantan are shrimp farms PT. Island Mas Equator which is Pinyuh River. In the process of shrimp culture ponds produce a lot of organic matter, high in organic matter is derived from the residual feed (pellets) are not depleted, in addition to the rest of the shrimp's metabolism also produces organic material. Therefore, to reduce the organic matter produced, PT Pulau Mas adding a probiotic (Bacillus sp.) Into shrimp feed. This study aims to determine the effect of probiotics on the quality of the waste water shrimp cultivation ponds and shrimp growth also physically. Stages of this research is the collection of primary data in the form of water sampling and measurement of the weight of shrimp. Water quality sampling using grab sample at two different pools, the pool with the addition of probiotics and probiotic ponds. Sampling was carried out two times, namely when shrimp aged 2 months and 3 months (harvest). The parameters were tested, namely BOD, COD, Ammonia, Nitrite and $\mathrm{pH}$. Based on the results of analysis show that the addition of probiotics in shrimp feed can mempenagruhi shrimp pond effluent water quality, evident from the decrease in concentrations greater than the swimming pool with the addition of probiotics without probiotics. Swimming with probiotics can reduce the BOD by $92 \%, 92 \%$ COD and Nitrite $75 \%$, while the decline in the pool without probiotics for BOD 
only by $74 \%$, COD $69 \%$ and $88 \%$ nitrite. The addition of probiotics in shrimp feed can affect the growth of shrimp. Shrimp with addition of probiotics have average growth - an average of 0.624 grams / day, while the shrimp without the addition of probiotics average growth - means are only of 0.41 grams / day.

Key words: Shrimp, Probiotics, Water Quality

\section{PENDAHULUAN}

Budidaya udang tambak adalah komoditas yang sangat menjanjikan keuntungan, tetapi juga banyak mengeluarkan limbah organik. Dampak lingkungan yang kurang baik dihasilkan dari perluasan tambak yang tidak terkendali pada sebagian wilayah pesisir di wilayah tropis dan subtropis. Kondisi ini menimbulkan kritik yang luas, dan secara global sebenarnya telah mendapatkan arahan dalam mengembangkan teknik budidaya yang lebih berkelanjutan (Naylor et al, 1998). Perkembangan teknologi budidaya udang dari sistem tradisional menjadi sistem semi intensif dan intensif menjadi permasalahan bagi perairan pesisir, terutama tingginya buangan limbah organik dari kegiatan pertambakan. Limbah organik dari tambak salah satunya berhubungan dengan penggunaan pakan (pellet). Pakan (pellet) yang digunakan untuk mendukung pertumbuhan udang pada tambak intensif dan semi intensif tidak seluruhnya termanfaatkan udang, kira-kira 35\% dari pakan yang diberikan merupakan limbah organik dimana $15 \%$ berupa sisa pakan dan $20 \%$ berupa sisa metabolisme (Naylor et al, 1998). Salah satu penyebab penurunan kualitas perairan tambak selama operasional adalah konsentrasi tinggi dari limbah organik dan nutrien sebagai konsekuensi dari masukan akuainput dalam budidaya udang yang menghasilkan sisa pakan dan feces yang terlarut ke dalam air (Boyd et al,1998).

Permasalahan lain adalah padatnya penebaran benur yang merupakan pemasok utama limbah bahan organik dan nutrien ke lingkungan perairan (Barg, 1991) serta menyebabkan pengkayaan nutrien (hypernutrifikasi) dan bahan organik yang diikuti oleh eutrofikasi dan perubahan ekologi fitoplankton, peningkatan sedimentasi, siltasi (terjadinya pengendapan), hypoxia (berkurangnya oksigen), perubahan produktivitas, dan struktur komunitas benthos (Barg, 1992). Padat tebar yang tinggi diikuti dengan pemberian pakan yang lebih banyak per satuan luas tambak akan menambah berat beban perairan tambak, yang nantinya selain dapat mempengaruhi pertumbuhan udang didalam kolam budidaya udang tersebut juga akan mempengaruhi kualitas air buangan kolam tersebut ketika dibuang ke badan air.

Situasi ini jika dilakukan secara terus menerus tanpa memperhatikan keselarasan dan keseimbangan dengan lingkungan akibatnya dari waktu ke waktu akan terjadi akumulasi bahan organik akibat dari sisa pakan dan kotoran udang yang berasal dari dalam tambak. PT. Pulau Mas Khatulistiwa sebagai salah satu perusahaan budidaya udang bertaraf Internasional memiliki beberapa wilayah untuk pengembangbiakkan udang vanname, salah satunya yang berlokasi di daerah Sungai Pinyuh, Provinsi Kalimantan Barat. Dalam budidaya udang tambak yang dilakukan di perusahaan, pihak perusahaan menambahkan probiotik kedalam pakan (pellet) dan kedalam kolam budidaya udang tambak tersebut. Penerapan penambahan probiotik ini diterapkan oleh pihak perusahaan karena mempunyai beberapa keuntungan, selain dapat mempengaruhi kualitas pertumbuhan udang juga dapat mempengaruhi kualitas air buangan. 
Probiotik yang dimaksud merupakan mikroorganisme hidup sejenis maupun campuran atau produk fermentasi mikrobiologi, yang dimasukkan ke dalam pakan sebagai makanan tambahan (feed supplement), dengan tujuan dapat meningkatkan pertumbuhan udang serta mampu mengatur / memelihara keseimbangan kondisi mikroflora (mikroorganisme dalam tubuh) serta mengurangi bakteri pathogen penyebab penyakit di dalam tubuh (usus umumnya) serta memperbaiki kualitas air buangan (Poernomo, 2004). Penelitian ini dilakukan untuk mengetahui seberapa efektif pengaruh penambahan probiotik terhadap kualitas air buangan dan pertumbuhan udang.

\section{METODE PENELITIAN}

\section{Data Kualitas Air buangan}

Data kualitas air buangan diperlukan untuk mengetahui konsentrasi yang terjadi pada masing-masing kolam yaitu tanpa probiotik dan menggunakan probiotik. Sehingga untuk memperoleh data kualitas air buangan maka dilakukan pengambilan sampel air pada masing-masing kolam. Sampel air ini diambil pada pipa buangan air kolam. Adapun waktu pengambilan sampel dilakukan dua kali, yakni pada saat 2 bulan dan 3 bulan (panen).

\section{Data Pertumbuhan udang}

Data pertumbuhan udang diperlukan untuk mengetahui pertumbuhan udang rata-rata pada pada masing-masing kolam yaitu tanpa probiotik dan menggunakan probiotik. Sehingga untuk memperoleh data pertumbuhan udang maka dilakukan pengambilan sampel udang pada masing-masing kolam. Sampel udang ini di ambil pada anco (alat kontrol pakan udang) masing-masing kolam. Adapun waktu pengambilan sampel dilakukan dua kali, yakni pada saat 2 bulan dan 3 bulan (panen).

\section{Anlisis Hasil}

Analisis yang dilakukan meliputi analisis kualitas air buangan dan pertumbuhan udang pada masing-masing kolam yaitu tanpa probiotik dan probiotik.

\section{Analisis air buangan (probiotik dan tanpa probiotik)}

Merupakan analisis untuk mengetahui kualitas air buangan pada masing - masing kolam tanpa probiotik dan probiotik yang berada di wilayah tambak Sungai Pinyuh dengan melakukan uji terhadap parameter-parameter air yang dilakukan di laboratoriom dinas kesehatan yang dapat dilihat pada Tabel 3

Tabel 3 Metode analisis air buangan

\begin{tabular}{ccc}
\hline No & PARAMETER & METODE \\
\hline 1 & $\mathrm{pH}$ & pH meter \\
2 & COD & Method $8000(\mathrm{HACH})$ \\
3 & BOD & BOD meter \\
4 & Amoniak & Spektrofotometri \\
5 & Nitrit & Spektrofotometri \\
\hline
\end{tabular}


Hasil uji parameter-parameter tersebut kemudian dibandingkan dengan baku mutu air buangan sesuai keputusan mentri LH No. 28 tahun 2004 tentang Pedoman Budidaya Udang di Tambak.

\section{Analisis pertumbuhan udang}

Merupakan analisis untuk mengetahui pertumbuhan udang tambak pada masing-masing kolam tanpa probiotik dan probiotik yang berada di wilayah sungai pinyuh dengan melakukan pengukuran dari rentang udang ke 1-10, udang ke 11-20, udang ke 21-30, udang ke 31-40 dan udang ke 41-50, setelah mendapatkan berat total dari masing-masing rentang, kemudian ditotalkan berat rata-rata, selanjutnya diukur pertumbuhan rata ratanya yaitu (kusuma, 2009) :

$$
G=\frac{W t-W o}{T}
$$

Keterangan:

$$
\begin{array}{ll}
\mathrm{G} & =\text { pertumbuhan udang } \\
\mathrm{T} & =\text { waktu ( hari) } \\
\mathrm{W}_{\mathrm{o}} & =\text { berat atau panjang mula }- \text { mula ( } 2 \text { bulan) } \\
\mathrm{W}_{\mathrm{t}} & =\text { berat atau panjang akhir (panen) }
\end{array}
$$

pertumbuhan Udang (tanpa probiotik / probiotik):

$$
\frac{W t(\text { panen })-W o(\text { dua bulan })}{30}
$$

Hasil dari analisis pertumbuhan udang dengan menggunakan rumus diatas dapat mempermudah mengetahui pengaruh penambahan probiotik terhadap pertumbuhan udang pada masing-masing kolam penelitian. Pelaksanaan pengambilan sampel udang dilakukan dua kali, dengan cara yang sama yaitu pada tahap 2 bulan dan 3 bulan (panen).

\section{HASIL DAN PEMBAHASAN}

\section{Kualitas Air Buangan Budidaya Udang Tambak}

Kualitas air limbah/buangan budidaya udang tambak dapat disebabkan oleh 2 faktor yaitu faktor eksternal (yaitu faktor dari luar pertambakan umumnya disebabkan oleh adanya kandungan bahan organik) dan faktor internal (akibat dari kelebihan pakan, hasil ekskresi dari hewan budidaya dan kondisi dasar tambak).

Air buangan tambak mengandung bahan-bahan cemaran yang bersumber dari sisa-sisa pakan, hasil ekskresi metabolit, detritus, mikroorganisme, dan residu berbagai bahan pengendali lingkungan dan penyakit. Bahan-bahan tersebut pada umumnya dapat mencemari air di lingkungan alami tambak. Oleh karena itu, setiap kegiatan budidaya udang harus melakukan perbaikan kualitas air buangan tambak agar dapat memenuhi Baku Mutu Efluen (KepMen LH 2004). Hasil uji kualitas air buangan disajikan dalam Tabel 1 dan Tabel 2 yang menunjukkan hasil uji kualitas air buangan pada masing-masing kolam dari tahap 2 bulan dan panen, 3 bulan. 
Tabel 1 Hasil analisis uji kualitas air buangan (Tanpa probiotik)

\begin{tabular}{cccccc}
\hline No & $\begin{array}{c}\text { Parameter } \\
(\mathrm{mg} / \mathrm{l})\end{array}$ & $\begin{array}{c}\text { (T. P) } \\
2 \text { bulan }\end{array}$ & $\begin{array}{c}\text { (T. P) } \\
3 \text { bulan }\end{array}$ & $\begin{array}{c}\text { Efisiensi } \\
\text { penurunan }\end{array}$ & Baku Mutu \\
\hline 1 & Amoniak & 3,6 & 10 & & $<0,1$ \\
2 & COD & 1590 & 497 & $74 \%$ & $<25$ \\
3 & BOD & 1034 & 323 & $69 \%$ & $<45$ \\
4 & Nitrit & 0,1 & 0,012 & $88 \%$ & $<2,5$ \\
5 & pH & 6,74 & 8,78 & & $6-9,0$ \\
\hline
\end{tabular}

Keterangan: T.P (tanpa probiotik)

Hasil analisis uji kualitas air buangan (tanpa probiotik) mengalami efisiensi penurunan saat kondisi 2 bulan dan 3 bulan (panen) untuk COD sebesar 74\%, BOD sebesar $69 \%$ dan nitrit sebesar $88 \%$.

Tabel 2 Hasil analisis uji kualitas air buangan (probiotik)

\begin{tabular}{|c|c|c|c|c|c|}
\hline No & $\begin{array}{c}\text { Parameter } \\
(\mathrm{mg} / \mathrm{l})\end{array}$ & $\begin{array}{c}(P) \\
2 \\
\text { bulan }\end{array}$ & $\begin{array}{c}(\mathrm{P}) \\
3 \\
\text { bulan }\end{array}$ & $\begin{array}{l}\text { Efisiensi } \\
\text { penurunan }\end{array}$ & Baku Mutu \\
\hline 1 & Amoniak & 3,2 & 5 & & $<0,1$ \\
\hline 2 & COD & 1620 & 134 & $92 \%$ & $<25$ \\
\hline 3 & BOD & 1053 & 87 & $92 \%$ & $<45$ \\
\hline 4 & Nitrit & 0,06 & 0,015 & $75 \%$ & $<2,5$ \\
\hline 5 & $\mathrm{Ph}$ & 6,87 & 6,91 & & $6-9,0$ \\
\hline
\end{tabular}

Keterangan: $\mathrm{P}$ (probiotik)

Hasil analisis uji kualitas air buangan (probiotik) mengalami efisiensi penurunan saat kondisi 2 bulan dan 3 bulan (panen) untuk COD sebesar 92\%, BOD sebesar 92\% dan nitrit sebesar $75 \%$. Kualitas air buangan yaitu sifat air buangan dan kandungan makhluk hidup, zat, energi atau komponen lain di dalam air. Kualitas air dinyatakan dalam beberapa parameter, yaitu parameter fisika, kimia dan biologi. Pembahasan kualitas air buangan didasarkan pada analisis data laboratorium terhadap beberapa parameter yang dibandingkan dengan baku mutu air buangan menurut KepMen LH Nomor 28 Tahun 2004. $\mathrm{pH}$

Secara umum $\mathrm{pH}$ sampel air buangan udang tambak yang dianalisis mengalami perbaikan selama tahap 2 bulan dan tahap 3 bulan (panen) baik kolam tanpa probiotik maupun kolam probiotik. Pada tahap 2 bulan kolam tanpa probiotik kondisi $\mathrm{pH}$ sampel air buangan tambak berada pada tingkat yang cukup rendah, yaitu sebesar 6,74 dan kolam probiotik sebesar 6,87 . Rendahnya nilai $\mathrm{pH}$ pada masing-masing sampel air buangan budidaya udang tambak dapat disebabkan oleh tingginya jumlah bahan organik, selain itu rendahnya nilai $\mathrm{pH}$ menunjukkan adanya peningkatan konsentrasi $\mathrm{CO}_{2}$ karena aktivitas mikroba dalam menguraikan bahan organik (Alabaster dan Lloyd, 1982 dalam Sari, 2007 dan Allan, 1995 dalam Sari, 2007)

\section{Amoniak}

Berdasarkan hasil analisis kualitas air yang telah dilakukan, diketahui bahwa kandungan amoniak pada kedua kolam dengan masing-masing perlakuan baik tanpa probiotik 
maupun dengan probiotik masih berada diatas ambang batas yang diizinkan. Namun, hsdil kedua kolam menunjukkan hasil yang berbeda yaitu sebesar $3,6 \mathrm{mg} / \mathrm{l}$ (kolam tanpa probiotik) dan 3,2 mg/l (kolam probiotik). Hal ini disebabkan adanya perbedaan degradasi bahan organik yang dilakukan oleh mikroorganisme yang sebelumnya telah tumbuh serta adanya penambahan bakteri melalui probiotik yang dapat membentuk bioflok. Bioflok terjadi ketika ketersediaan oksigen mencukupi (Harris,1986), sehingga dapat dimanfaatkan oleh alga untuk memanfaatkan amoniak untuk menghasilkan nitrit dan nitrat melalui proses nitrifikasi.

\section{COD}

Berdasarkan hasil analisis kualitas air yang telah dilakukan, diketahui bahwa kandungan COD pada kedua kolam baik pada tahap 2 bulan dan 3 bulan (panen) tanpa probiotik maupun probiotik masih berada dalam ambang batas yang tidak diizinkan. Hasil penelitian menunjukkan kondisi 2 bulan konsentrasi COD tanpa probiotik dan probiotik masingmasing sebesar $1590 \mathrm{mg} / \mathrm{l}$ dan $1690 \mathrm{mg} / \mathrm{l}$. Hal ini menunjukkan perbedaan hasil diantara kedua kolam yaitu kolam tanpa probiotik menghasilkan nilai COD yang lebih rendah dibandingkan kolam probiotik.

Hasil penelitian tersebut menunjukkan kandungan pakan yang diberikan tidak mengandung bahan tambahan yang berlebih seperti protein dan lemak (soediaoetomo, 1991) yang berasal dari buangan metabolisme, sehingga sisa metabolit tersebut akan terdegradasi walaupun lambat melalui bantuan mikroorganisme yang tumbuh secara alami, sedangkan untuk kolam probiotik menghasilkan nilai COD yang lebih tinggi dikarenakan pakan probiotik yang mengandung nutrisi tinggi seperti protein dan lemak tidak termakan secara sempurna oleh udang saat usia 2 bulan dikarenakan udang mempunyai sifat pemakan yang lambat, sehingga sisa pakan akan mudah berakumulasi dengan sisa metabolisme udang kemudian akan mengendap menjadi lumpur didasar tambak (Siswanto, 2002).

\section{BOD}

Nilai BOD yang tinggi mengindikasikan bahwa bahan pencemar yang ada dalam air buangan tersebut juga tinggi. Hal ini menunjukkan semakin besarnya bahan organik yang terdekomposisi menggunakan sejumlah oksigen di perairan. Berdasarkan hasil analisis kualitas air buangan yang telah dilakukan, diketahui bahwa kandungan BOD pada kedua kolam baik pada saat 2 bulan dan 3 bulan (panen) tanpa probiotik maupun maupun probiotik masih berada dalam ambang batas yang tidak diizinkan.

Dilihat dari Gambar 4.4 pada kondisi 2 bulan konsentrasi BOD tanpa probiotik dan probiotik masing-masing sebesar $1034 \mathrm{mg} / \mathrm{l}$ dan $1053 \mathrm{mg} / \mathrm{l}$. Hal ini menunjukkan adanya perbedaan hasil diantara kedua kolam yaitu kolam tanpa probiotik menghasilkan nilai BOD yang lebih rendah dibandingkan kolam probiotik sama hal nya pada uji COD. Hal ini dikarenakan kandungan pakan yang diberikan tidak mengandung bahan tambahan yang berlebih seperti lipid dan protein yang dapat menambah buangan sisa metabolisme terlalu banyak (Dall dan Smith, 1986), yang dikarenakan udang mempunyai kapasitas terbatas dalam menyimpan senyawa - senyawa cadangan tersebut. Hal ini membuat berkurangnya ekskresi bahan organik bernitrogen yang dikeluarkan (baik yang berasal melalui feces maupun metabolisme) maupun pakan yang tidak termakan dalam jumlah 
yang besar, sehingga masih dapat terdegradasi walaupun lambat melalui bantuan mikroorganisme yang tumbuh secara alami. Selanjutnya untuk kolam probiotik menghasilkan nilai BOD yang lebih tinggi dikarenakan kondisi udang 2 bulan merupakan udang yang dikategorikan masih muda, mempunyai metabolisme yang lebih tinggi serta komponen pakan yang diberikan lebih banyak, menyebabkan sisa - sisa pakan yang tidak termakan udang lebih besar yang dapat membuat bahan organik tersebut berakumulasi dan mengendap menjadi lumpur didasar tambak. Selain itu sifat pemakan lambat yang dimiliki oleh udang menyebabkan pakan yang belum termakan mudah larut di dalam air dan akhirnya menambah akumulasi bahan organik didalam kolam (Siswanto, 2002)

\section{Nitrit}

Nilai nitrit menunjukkan senyawa-senyawa nitrogen organik yang larut dalam air maupun yang berupa zarah dan yang berasal dari organisme yang mati atau merupakan hasil ekskresi tumbuhan maupun udang cepat dirombak menjadi amoniak. Terlihat dari kandungan nitrit pada kedua kolam baik pada tahap 2 bulan dan 3 bulan (panen) tanpa probiotik maupun probiotik masih berada dalam ambang batas yang diizinkan. Gambar 4.5 menunjukkan kondisi 2 bulan konsentrasi nitrit tanpa probiotik dan probiotik masingmasing sebesar $0,1 \mathrm{mg} / \mathrm{l}$ dan $0,06 \mathrm{mg} / \mathrm{l}$. Hal ini dikarenakan adanya Proses perombakan yang baik untuk masing-masing kolam oleh suatu proses bakterial oleh bakteri-bakteri proteolitik yang terdapat dalam pakan yang telah diberikan penambahan probiotik maupun yang terdapat secara alami di dalam kolam. Bakteri proteolitik ini merupakan bakteri yang mampu mendegradasi lemak dan protein dengan baik yang dihasilkan dari sisa metabolisme udang di dalam kolam lingkungan (Nooris et al., 1981). Sedangkan untuk kondisi 3 bulan tanpa probiotik dan probiotik yaitu masing-masing sebesar 0,012 $\mathrm{mg} / \mathrm{l}$ dan $0,015 \mathrm{mg} / \mathrm{l}$. Hal ini menunjukkan adanya penurunan yang baik untuk konsentrasi nitrit pada masing-masing kolam dari kondisi sebelumnya, dapat dilihat pada kolam tanpa probiotik nitrit mengalami penurunan sebesar $0,012 \mathrm{mg} / \mathrm{l}$ dikarenakan adanya bakteri autotrof yang tumbuh secara alami didalam kolam seiring berjalannya proses budidaya udang. Sehingga dapat membantu proses nitrifikasi di dalam air.

\section{Analisis pertumbuhan udang}

pertumbuhan dapat diartikan sebagai pertambahan ukuran panjang atau berat dalam suatu waktu. Akan tetapi apabila kita lihat lebih lanjut, sebenarnya pertumbuhan merupakan proses biologis yang kompleks dimana banyak faktor (Effendie, 1997). Berikut adalah hasil pengukuran pertumbuhan udang yang dilihat dari beratnya.

Tabel 3 Hasil analisis pertumbuhan udang

\begin{tabular}{ccc|cc}
\hline \multirow{2}{*}{$\begin{array}{c}\text { Sampel } \\
\text { udang } \\
\text { ke- }\end{array}$} & \multicolumn{2}{c|}{$\begin{array}{c}\text { Berat udang } 2 \text { bulan } \\
\text { (gram) }\end{array}$} & \multicolumn{2}{c}{ Berat udang 3 bulan, panen (gram) } \\
\cline { 2 - 5 } & Probiotik & $\begin{array}{c}\text { tanpa } \\
\text { probiotik }\end{array}$ & Probiotik & $\begin{array}{c}\text { tanpa } \\
\text { probiotik }\end{array}$ \\
$1-10$ & 115 & 107 & 244 & 264 \\
$11-20$ & 122 & 122 & 290 & 246 \\
$21-30$ & 112 & 108 & 350 & 182 \\
$31-40$ & 119 & 106 & 316 & 234 \\
\hline
\end{tabular}




\begin{tabular}{ccccc}
\hline $\begin{array}{c}41-50 \\
\text { Berat } \\
\text { total }\end{array}$ & 120 & 124 & 324 & 258 \\
$\begin{array}{c}\text { Berat } \\
\text { rata-rata }\end{array}$ & 11,76 & 11,34 & 1524 & 1184 \\
\hline
\end{tabular}

Hasil pengukuran pertumbuhan udang yang disajikan pada Tabel 3 menggunakan perhitungan sebagai berikut:

Pertumbuhan udang (tanpa probiotik):

$\frac{W t(\text { panen })-W o(\text { dua bulan })}{30}$

Diketahui: berat rata-rata (tanpa prob) 2 bulan

berat rata-rata (tanpa prob) 3 bulan (panen)
$=11,34$ gram

$=23,68$ gram

Ditanyakan: pertumbuhan total kolam tanpa probiotik? Jawab:

$$
\frac{23,68-11,34}{30}=0,41 \text { gram } / \text { hari }
$$

Pertumbuhan udang (probiotik):

$\frac{W t(\text { panen })-W o(\text { dua bulan })}{30}$

Diketahui: berat rata-rata (tanpa prob) 2 bulan $\quad=11,76$ gram

Ditanyakan: pertumbuhan total kolam tanpa probiotik? Jawab:

$$
\frac{30,48-11,76}{30}=0,624 \text { gram }
$$

Hasil pengukuran dan perhitungan diatas menunjukkan adanya perbedaan berat udang pada masing-masing kolam pada kondisi 2 bulan, yaitu pada kolam tanpa probiotik, dikarenakan nutrisi yang diberikan dalam pakan kurang mengandung nutrisi yang dibutuhkan oleh udang khususnya penambahan probiotik, sehingga berat yang dihasilkan tidak menunjukkan kestabilan berat yang sama. Faktor lain yaitu pengkayaan pakan seperti penambahan probiotik sangat diperlukan sekali karena suplai dari alam sudah sangat terbatas (Kokarkin dan Kontara, 2000), selain itu yang menyebabkan rendahnya berat udang dalam kolam tersebut adalah tidak diberikannya penambahan probiotik sehingga menyebabkan kurangnya nafsu makan, kurangnya daya cerna yang baik sehingga pertumbuhan udang menjadi kurang baik serta membuat pakan mudah terurai dalam air, disebabkan oleh sifat udang sebagai pemakan yang lambat membuat sisa pakan yang tidak termakan berakumulasi dengan bahan organik lainnya dan menyebabkan pakan tidak termakan oleh udang (Clara dan Suhardjo, 1988). 


\section{KESIMPULAN}

Dari hasil penelitian yang telah dilakukan kesimpulan yang dapat diambil adalah sebagai berikut:

a) Penambahan probiotik pada pakan udang dapat mempengaruhi kualitas air buangan tambak udang, terlihat dari adanya penurunan konsentrasi yang lebih besar pada kolam dengan penambahan probiotik dibandingkan kolam tanpa probiotik, namun konsentrasi yang dihasilkan masih melebihi baku mutu yang diizinkan KepMen LH TH 2004 . Kolam dengan probiotik dapat menurunkan BOD sebesar $92 \%$, COD $92 \%$ dan Nitrit $75 \%$, sedangkan penurunan yang terjadi pada kolam tanpa probiotik untuk parameter BOD hanya sebesar $74 \%$, COD $69 \%$ dan Nitrit $88 \%$.

b) Penambahan probiotik pada pakan udang dapat mempengaruhi pertumbuhan udang. Udang dengan penambahan probiotik memiliki pertumbuhan rata - rata sebesar 0,624 gram/hari, sedangkan udang tanpa penambahan probiotik pertumbuhan rata - ratanya hanya sebesar 0,41 gram/hari.

\section{UCAPAN TERIMAKASIH}

Dengan selesainya penelitian ini saya mengucapkan terima kasih yang sebesar-besarnya kepada ALLAH SWT, kedua orang tua, kedua dosen pembimbing saya yaitu Ibu Siti Khotimah dan Ibu Isna Apriani serta kepada teman-teman Teknik Lingkungan 2010 dan semua yang telah berperan dalam membantu penelitian yang tidak dapat di ucapkan satu persatu. Harapan saya penelitian ini dapat bermanfaat bagi semua dan dapat dipergunakan sebagaimana mestinya.

\section{DAFTAR PUSTAKA}

Barg, U.C. 1992. Guidelines for the promotion of environmental management of coastal aquaculture development. FAO Fisheries Technical Paper 328, FAO, Rome. 122p.

Boyd. 1998. Water Quality in Warmwater Fish Ponds. Alabama Agricultural Experiment Station. United States. $359 \mathrm{~h}$.

Clara dan Suhardjo. 1988. Prinsip-prinsip ilmu gizi. Pusat Antar Universitas-IPB, LSI, Bogor

Dall, W. and Smith, D.M. 1986. Oxygen consumption and ammonia-N excretion in fed and starved tiger prawns Penaeus esculentus Haswell. Aquaculture, 55:23-33.

Effendi, H. 1997. Telaah Kualitas Air : Bagi Pengelolaan Sumberdaya dan Lingkungan Perairan. Kanisius. Yogyakarta. $258 \mathrm{~h}$.

Kepmen perikanan dan kelautan. 2004. Pedoman umum budidaya udang di tambak. Departemen kelautan dan perikanan. Jakarta.

Kokarkin, C. dan Kontara, E.K. 2000. Pemeliharaan udang windu yang berwawasan lingkungan. Sarasehan Akuakultur Nasional, Bogor Lagrega,MD, PL Buckingham, J.C Even, 1994. Hazartus Waste Management. Mac. Graw Hill Inc.

Kusuma. 2009. Budidaya Udang. Fakultas Perikanan dan Ilmu kelautan. Institut Pertanian Bogor (IPB). Bogor. 
Naylor, R.L., Goldburg, R.J., Mooney, H., Beveridge, M., Clay, J., Folke, C., Kautsky, N., Lubchenco, J., Primavera, J., Williams, M. 1998. Nature's subsidies to shrimp and salmon farming. Science $282,883-884$.

Nooris, J.R., R.C.W. Berkeley, N.A.Logan, and A.G. O'Donnell. 1981. The Genera Bacillus and Sporalactobacillus. In : The Prokary- otes, vol 2 (Starr, M.P., Stolp, A., Truper, A.G., Balows, A., and SchlegelL, H.G., eds). Springer -Verlag, New York : 1711 1742 .

Sari. 2007. Kualitas Sungai Maron Dengan Perlakuan Keramba Ikan di Kecamatan Trawas, Kabupaten MojoKerto, Jawa Timur. Bioceint., 4(1), 2007, 29-35.

Sediaoetomo, A.D. 1991. Ilmu gizi. Dian Rakyat, Jakarta. Soley, N., A. Neiland and D. Nowell, 1994. An economic approach to pollution control in aquaculture. Marine Pollution Bulletin, Vol.28(3).

Siswanto, 2002. Metode Penelitian Air. Surabaya : Usaha Nasional. 